\title{
SAKRAMENTALNE UOBECNIENIE PASCHY CHRYSTUSA
}

Chrystus stał się naszą Paschą przez tajemnice swej męki, śmierci, zmartwychwstania i wniebowstąpienia. Tajemnice te składające się na całość tajemnicy paschalnej stanowią centralne i szczytowe wydarzenia całego życia Jezusa Chrystusa i Jego działalności zbawczej. To przede wszystkim przez tajemnicę paschalną Chrystus dokonał Odkupienia, założył Kościół i zapewnił skuteczność jego zbawczemu pośrednictwu. Całŷ Kościół wciąż żyje tajemnicą paschalną Chrystusa i jest przekonany o jej wiecznotrwałej wartości. Na jej pamiątkę sprawuje liturgię, zwłaszcza Eucharystyczną ofiarę. Warto jednak pokusić się o głębsze wyjaśnienie związku tajemnicy paschalnej z życiem Kościoła i z Jego liturgią.

Teologia szkolna przed ostatnim Soborem wyjaśniała na ogół, że ofiara paschalna Chrystusa była przyczyną zasługującą wiecznotrwałych skutków zbawczych, zwłaszcza łaski usprawiedliwiającej i te skutki zbawcze są nam dostępne w liturgii, a zwłaszcza w sakramentach św. Jedynie w Eucharystii jest jakieś tajemnicze, ale rzeczywiste uobecnienie ofiary krzyża. Nauczano też, że sakramenty św., udzielając łask płynących z tajemnicy paschalnej, zobowiązują chrześcijan do naśladowania Chrystusa umierającego i zmartwychwstałego przez codzienne umieranie dla grzechu i wzrastanie w łasce, będącej zadatkiem zmartwychwstania ${ }^{1}$.

Już jednak w okresie międzywojennym zrozumiano potrzebę głębszego ujęcia wiecznotrwałej wartości tajemnicy paschalnej oraz ścisłych związków ze skutecznością posłannictwa Kościoła, a zwłaszcza ze skutecznością sakramentów. Podjęto też w związku z tym pierwsze próby odnowy sakramentologii w powiązaniu z chrystologią i eklezjologią. Wiele było przyczyn tej odnowy. Rozwój ruchu liturgicznego kazał pogłębiać refleksje nad przeżywaniem w liturgii zbawczych misteriów Chrystusa ${ }^{2}$. Gruntowne studia biblijne i patrystyczne ukazały ścisły związek terminu ,sakrament” z terminem ,misterium” oraz ogromne bogactwo znacze-

1 Por. np. ks. W. Gran at, Dogmatyka katolicka, t. IV, Lublin 1960, s. 89 93 i $1.013-108$; t. VIII/1, Lublin 1961), s. $88-1113$, $3313-3440$ i $382-401$.

2 O ruchu liturgicznym por. m.in. Liturgika ogólna, Lublin 1973, s. 3016-315 (Tem fragment dzieła zbiorowego oprac. ks. M. Z a hajikiewic z); P i us XII, Encyklika o liturgii (Mediatior Dei), Kielce 1948, s. 6-113) (fragment W'steppu opracowanego przez tłumacza Encykliki, O. J. W i erusza-Kowa lsiki i go). 
nia tych pojęć w starożytności chrześcijańskiej. „Misterium” to przede wszystkim objawienie i realizowanie $\mathrm{w}$ widzialnych wydarzeniach zbawczego działania Bożego oraz jakieś przypominanie i uobecnianie wydarzeń zbawczych $\mathrm{w}$ widzialnych obrzędach Kościoła ${ }^{3}$. Wyniki tych badań wpłynęły na rozwój sakramentologii i teologii liturgii, zwłaszcza na głębsze wyjaśnienie tajemnicy uobecniania ofiary krzyża w sprawowaniu Eucharystii, na ukazywanie paschalnego charakteru poszczególnych sakramentów, na rozwój teologii roku kościelnego, na pogłębienie pojęć anamnezy, uczestnictwa itd. ${ }^{4} \mathrm{Nie}$ bez znaczenia był także rozwój eklezjologii i chrystologii. W eklezjologii mocno uwydatniono prawdę, że Kościół nie jest tylko instytucją zbawczą działającą w imieniu Chrystusa, z Jego pełnomocnictwa i zawierającą w sobie moce zbawcze będące skutkiem czy owocem zbawczych czynów Jezusa, zwłaszcza tajemnicy paschalnej, ale jest, jako mistyczne ciało Chrystusa i Jego sakrament, $\mathrm{w}$ szczególny sposób zjednoczony czy nawet utożsamiony $\mathrm{z}$ uwielbionym Chrystusem jako swą Głową. W życiu i działalności Kościoła, zwłaszcza w jego liturgii, jest wielorako obecny i działający uwielbiony Zbawiciel, a wraz z Jego osobą jest także jakoś tajemniczo uobecnione całe Jego dzieło zbawienia, zwłaszcza tajemnica paschalna ${ }^{5}$. Chrystologia wspól-

$s$ Historię i wyniki tych badań przøidstawiają m.in. L. B off (Die Kirche als Sakrament im Horizont der Welterfahrung, Paderborn 1972, s. 48-1103) i Y. Cong a r (Kościót jako sakrament zbawienia, tł. Mazuś, Warszawa 1930, s. 25-29, 47-55). Francuski oryginal tego dzieła pit. Un peuple messianique ukazał się $\mathrm{W} \mathrm{Pa}-$ ryżu w 1975 r.).

${ }^{4}$ Spośród pozycji polskich por. min. Wprowadzenie do liturgii. P r a c a z b i orow a, Poznań-Warszawa-Lublin 1967, zwł. s. 9-134; Sakramenty Kościoła posoborowego. Kraków 197.0; Liturgia ogólna, s. 19-138; R. Goczo1, Anamneza. II. W teologii, w: Encyklopedia katolicka, t. I, Lublin 1973, kol. 511-5112; W. Swli r z a s ki, Mysterium Christi. Chrystus obecny w liturgii i życie chrześcijańskie, Kraków 1975; T enż e, Dynamiczna „pamiatka” Pana. Eucharystyczna anamneza Misterium Paschalnego $i$ jego egzystencjalna dynamika, Kraków 1980; Sakramenty wtajemniczenia chrześcijańskiego, War|szawa 1981, zwł. s. $9-$ $16,33-42,51-59,193-266 ; k s$. A. L. S z a f r a ń s k i, Teologia liturgii eucharystycznej, Lublin' 1981 ; ks. J. Gr z és k o w i a k, Liturgia dziś, Katowice 1982; ks. B. M okrzy cki, Droga chrześcijańskiego wtajemniczenia, Warszawa 1983, s. 13-33.

${ }_{5}$ Spośród bardzo licznyich pozycji odnowionej eklezjologii, jakie zaczęly się ukazywać zwłaszcza od lat dwudziestych obecnego stuliecia, wymieńmy przykładowo kilka, które opublikowano w naszym kraju jeszcze w olkresie przedlsoborowym: K. A d a m, Istota katolicyzmu (tł. kis. J. Korzonkiewicz), Poznań 1930; A. T y mc z a k, Kościól jako mistyczne ciato Chrystusa, Lwów 19311; W. St a niszews ki, Kościót jako mistyczne ciało Chrystusa wedtug św. Augustyna, Lublin diłi36; W. Korniłowicz, Chrześcijańska odbudowa świata $w$ swietle nauki o Ciele Mistycznym, Warszawa 1938; F. J ürgerism e i e r, Mistyczne Ciało Chrystusa jako podstawa ascetyki, rozbudowy $i$ dażen życia religijnego (tł. S. Grelewskii), Lublin 1939; L. K a c z ma rek, Nauka o mistycznym ciele Chrystusa Pana, Poznań 1947; Y. de Montch euil, Wykłady o Kościele (tł. L. Whiewtórkownski), Warszawa 1956; W. Granat, Chrystus odkupiciel $i$ Kosciót - Jego Mistyczne Ciało, Lublin 1960; K. Journet, Kościól Chrystusowy. Teologia o Kościele (tł. M. Stokowska), Poznań-Warszawa-Lublin 1960; H. id e L u b a c, Katolicyzm. Społeczne aspekty dogmatu (tt. M. Stokowska), Kraków 1961. Po Soborze liczba pozycji poświęconych Kościołorwi jest jeszcze większa; najiczęściej są to komentarze do Konstytucji Lumen Gentium. 
czesna traktowana łącznie $\mathrm{z}$ soteriologią i powiązana $\mathrm{z}$ pneumatologią próbuje głębiej naświetlić tajemnicę wiecznej wartości i trwałości zbawczego dzieła Chrystusa oraz możliwości jego uobecniania się i oddziaływania poprzez ukazywanie ścisłej jedności między Chrystusem a Duchem Swiętym, jedności, która doszła do szczytu w wydarzeniu zmartwychwstania i która umożliwiła uwielbionemu Panu egzystowanie i działanie w świecie niejako na wzór Ducha ${ }^{6}$.

Na skutek tych wszystkich przyczyn mogła się rozwinąc nauka o sakramentalnym uobecnieniu Paschy Chrystusa nie tylko w samej ofierze Eucharystii, ale także w jakiejś mierze w całej liturgii i w całym życiu Kościoła. Ponieważ Eucharystia kształtuje z wspólnoty wierzących jedno mistyczne ciało Chrystusa, a cała liturgia jest źródłem i szczytem życia chrześcijańskiego, dlatego cały Kościół a w nim autentyczne życie chrześcijańskie można określić jako sakrament Paschy Chrystusa, jako jej znak i faktyczne uobecnienie, jako faktyczne włączenie się w Tajemnicę Paschalną czy jako uczestnictwo w niepowtarzalnych, ale wiecznotrwałych wydarzeniach śmierci i zmartwychwstania Chrystusa. Podstawami biblijnymi takiego określenia są zwłaszcza Pawłowe wypowiedzi o udziale przez chrzest i przez eucharystię w śmierci i zmartwychwstaniu Chrystusa ? Wypowiedzi te zostały ostatnio autorytatywnie przypomniane i wyjaśnione przez Sobór Watykański II w Konstytucji o Liturgii św. i w Konstytucji dogmatycznej o Kościele ${ }^{8}$.

W oparciu o te podstawy musi być podjęty wysiłek głębszego uzasadnienia i wyjaśnienia nauki o sakramentalnym uobecnieniu Paschy Chrystusa w Kościele a także samego określenia Kościoła jako sakramentu Paschy Chrystusowej. Pierwszą próbę jakiegoś głębszego naświetlenia tych zagadnień podjął $w$ okresie międzywojennym O. C a s el, tworząc głośną teorię misteryjną, która mówi o tzw. misteryjnej obecności zbawczych aktów Chrystusa, zwłaszcza wydarzenia paschalnego we wszystkich sakramentach świętych, a nawet $\mathrm{w}$ liturgii roku kościelnego ${ }^{9}$. Pew-

${ }^{6}$ Por. m.in. H. M ühlen, Das Christusereignis als Tat des Heiligen Geistes, w: Mysterium Salutis, Bd III/2, Ein'siede!-ZZ̈̈rich-Köln 1969, s. 513-5145; W. K a sp e r, Jezus Chrystus (tł. B. Białecki), Warszawa 1983, s. 255-279. Dobrą charakterystyke chrystologii zorientowanej pneumatologicznie podaje bp. A. N os s o l w artykule pt. Duch Swięty jako obecność Jezusa Chrystusa, „Coll. Theol." 50 (1980) z. 3, s. 5-24. Artykuł ten zamieszczony jest także w pracy bpa Nos sola pt. Teologia na usługach wiary. Wokól zagadnién odnowionej teologii, Opole 1978, s. 195-209. Por. też te g o ż autora, Duch Swięty a odnowienie świata, "Collectanea Theologica" 53 (1983) z. 2, s. $6-7$.

7 Por. Rz. 6, 3-11; 1 Kor 10, 16-17; 11, 23-29. Por. także Ef 5, 25-312, gdzie św. Parwel ukazuje głęboką więź przymierza małżeńskiego, z Przymierzem między Chrystusem a Kościołem, które zostało zawarte przez ofiarną śmierć Chrystusa.

${ }_{8}$ Por. zwłaszcza KL 6 i 7 (akapity 1 i 2 ) oraz KK 7 (akapity 2 is 5 ) i 11 (akapity 1 i 2 ).

8 Odo C a s e 1 (1886-11948) sformułował swoją teorię w wielu publikacjach. Por. np. Das Gedächtnis des Herrn in der altchristlichen Liturgie, Freiburg 1918; Die 
ne modyfikacje do tej teorii wprowadzili G. Söhnge n ${ }^{10}$ i A. V on i e ${ }^{11}$. Papież Pi us XII w enc. Mediator Dei nie odniósł się negatywnie do tej teorii i odrzucił tylko myśl o rzeczywistym uobecnianiu się konkretnych historycznych wydarzeń zbawczych w liturgii roku kościelnego ${ }^{12}$.

Dalsze próby wyjaśnień podjęto w latach pięćdziesiątych naszego wieku. L. Mo nden interpretował działanie samego Chrystusa w sakramentach przy pomocy terminu „przyczynowość symbolu”, co zdaniem E. Schillebeeckxa nie tłumaczy dostatecznie symboliki działania Chrystusa przez akt Kościoła jako znak i narzędzie tego dziıłania ${ }^{13}$. $\mathrm{K}$. R a h n e $\mathrm{r}$ mówił ogólnie, iż tajemnica Kościoła jest tylko poszerzeniem tajemnicy Chrystusa i ukazywał, iż samo Wcielenie już przesądzało o Odkupieniu przez krzyż i o trwaniu łaski Bożej w świecie, wkorzenionej w ludzkie ciało Chrystusa, będące cząstką ludzkości i jej historii $^{14}$. O. S e m m e l r oth wyjaśniał, iż Kościół w swej strukturze sakra-

Liturgie als Mysterienfeier, Freiburg 1922; Mysterium und Martyrium, „Jahrbuch für Liturgiewtissenschaft" 2 (1922), s. 18-38; Das Mysteriengedächtnis der Messliturgie im Lichte der Tradition, tamże 6 (1926), s. 113-12044; Mysteriengegenwart, tamże 8 (1928), s. 1445-224; Das christliche Kultmysterium, Regensiburg 1932, ${ }^{41960}$; Neue Zeugnisse für das Kultmysterium, ,Jahrbulch f. Lit. Wliss”. 13 (1933), s. 99171; Art und Sinn der ältesten christlichen Osterfeier, tamże 14 (19:38), s. $1-78$; Glaube, Gnosis und Mysterium, tamże 15 (1941), s. 155-3016; Das christliche Festmysterium, Paderborn 1941; Mysterium der Ekklesia, Mainz 1961; Das christliche Opfermysterium, Graz 1968. Por. też I. R ó ż y c k i, Podstawy sakramentologii, Kraków 19170, S. 1517-117:0; C. E. O'N eil1, Les sacraments, w: Bilan de la thénlogie $d u X^{e}$ siècle (sous la dir. de R. Van der Gucht et $\mathrm{H}$. Vorgrim le r), Tournai-Paris 1971, s. 462-464; R. G o c z ol, Casel Odo, w: Encyklopedia katolicka, t. II, Lublin 1976, kol. 1350-1351: (Bibliogr.); W. Sw i er z a wsik i, Mysterium Christi, s. 392-395 i 40.5-4066; t e nz ż e, Dynamiczna „pamiatka” Pana, s. 66, 71-73, $100-1101,241-242,272-274$ i $277-278$.

10 P.or. m.in. Symbol und Wirklichkeit im Kultmysterium, Bonn 19137, 21940; Der Wesensaufbau des Mysteriums, Bonn 1938; Das sakramentale Wesen des Messopfers, Essen 1946; Christi Gegenwart in uns durch den Glauben (Eph 3, 17), w: Messe in der Glaubenverkündigung, Freiburg 1953, s. 14-28; Christigegenwart in Glaube und Sakrament, München 1967, Leipzig 1968. Por. też m.in. W. S w i erzawski, Mysterium Christi, s. 1012-103; t enż e, Dynamiczna, ,pamiatka" Pana, s. $71-73$.

11 Pior. A key to the doctrine of the Eucharist, London 1925; The Spirit and the Bride, London 1935. Por. też m.in. K. J o u rn et, Msza swięta. Obecność ofiary krzyżowej (tł. M. Stokowska), Poznan-Warszawa-Luiblin 1959, s. 310-312; C. E. O'N e i 11 , Les sacrements, is. 461-162.

12 Por. Encyklika o liturgii (Mediator Dei), s. 86-91.

13 Por. L. Mond e n, Het Misoffer als Mysterie. Een studie over de heilige mis als sacramenteel offer in het licht van de mysterienleer van Dom Odo Casel, Roermond-IMaaseik 1948; T en ż e, Symbooloorzakelijkheid als eigen causaliteit van het sacrament, „Bijldragen" 13 (1952), s. 277-285; E. S chili e bee ckx, De sacramentele heilseconomie. Theologische bezinning op. S. Thomas sacramenteleer in het licht van traditie en van de hedendaagse sacramentsproblematiek, Antverpen-Bilthoven 19512, s. 223-230; T e nże, Chrystus sakrament spotkania $z$ Bogiem (tł. k.s. A. Zuberbier z przekładu ang.: Christ the Sacrament of the Encounter with God, New York 1968. Tytuł oryginału: Christus, sacrament van de Godsontmoeting, Bilthoven 1960), Kraków 1966, s. 11015.

14 Por. np. Kirche und Sakramente, Freiburg 1963 , zwl. s. $13-15$ oraz 72 i $78-$ 82; Zur Theologie der Menschwerdung. w: Schriften zur Theologie, Bd. IV, Ein- 
mentalnej jest odbiciem zbawczego dzieła Chrystusa. Jest sakramentalnym uobecnieniem tego dzieła $w$ jego istotnej, dialogicznej i dwufazowej strukturze (z jednej strony dzieło udzielania się Boga ludziom przez Wcielenie, a z drugiej - dzieło oddania się ludzkości Bogu w dokonanej przez Boga-Człowieka w imieniu ludzkości ofierze krzyża, w zmartwychwstaniu i wniebowstąpieniu). Urząd hierarchiczny w Kościele obrazuje, zastępuje i przedłuża funkcje samego Chrystusa, Pośrednika i Oblubieńca Kościoła, a społeczność wierzących, uświęcona w chrzcie i bierzmowaniu staje się Oblubienicą Chrystusa, która na podobieństwo Maryi przyjmuje z wiarą Słowo Boże i przez postawę ofiary wraca do Boga. Autor podkreślał przy tym mocno, że Kościół nie tylko obrazuje odkupieńcze dzieło Chrystusa, ale je w sposób obiektywny zawiera. Kontynuacją i uobecnieniem tego dzieła i jego dialogicznej struktury jest przede wszystkim liturgia Kościoła: przepowiadanie Słowa Bożego i sprawowanie sakramentów św. ${ }^{15}$ E. Schillebeeckx twierdził, że Chrystus Pośrednik jest nie tylko przekazicielem miłosierdzia Bożego dla ludzkości potrzebującej zbawienia, ale w swych aktach kultycznych jest przedstawicielem całej ludzkości. Całe życie Jezusa wyczerpuje się w czynach posłusznej miłości ku Bogu, która swój punkt kulminacyjny osiąga w śmierci mesjańskiej za lud. Odpowiedzią Boga Ojca na ten akt posłuszeństwa było wydarzenie zmartwychwstania, dzięki któremu Chrystus jako uwielbiony Pan posyła na ziemię Ducha Swiętego. Autor twierdził następnie, że Kościół na ziemi jest sakramentem Chrystusa żyjącego w niebie. Podkreślał przy tym, iż „Chrystus w swym już chwalebnym ciele jest sam eschatologiczną, zbawioną wspólnotą Odkupienia, czyli Kościołem. Chrystus chwalebny jest sam w sobie, równocześnie, Głową i członkami”. „Kościół na ziemi jest widzialnym ukazaniem ... rzeczywistości zbawienia w historii ... Zwycięstwo odniesione przez Chrystusa przejawia się w historycznej postaci Kościoła - zarówno w jego hierarchii jak i w świeckich wiernych". Ludzkie czyny zbawcze Jezusa, chociaż same w sobie należą do bezpowrotnej przeszłości i nie mogą być powtórzone, to jednak jako czyny Osoby Bożej mają charakter wiecznotrwały; sam akt ofiary krzyża jest

siedeln 1960, s. $137-155$. Por. też m.in. A. Sk ow ronek, Chrystologiczne podstawy Kościoła jako prasakramentu, ,Sląskie Studia Hist.-Teol." 1 (1963). s. 96-97 i 103; ks. B. Snela, Kościót i sakramenty, w: Wprowadzenie do liturgii, zwł. s. 67 i 73 .

15 Por. np. Die Kirche als Ursakrament, Frankfurt a. M. 19153, zwł. s. 158-160 i 166-206; Das Lebensgefühl der Gläubigen in der Kirche, „Greist und Leben” 27 (1954), s. 196; Das geistliche Amt, Frankfurt a. M. 1958, zwł. s. 41 i 48 ; Das Christusereignis und unser Heil, ,Trierer Theol. Zeitschrift" 68 (1959), s. 337 i 346; Wortverkündigung und Sakramentenspendung als dialogisches Zueinander, "Catholica" 15 (1961), s. 49-60; Zur Theologie der Sakramente, ,Lebendige Seelsorge” 13 (1962), s. 232. Por. też m.in. W. Hrynie wic z, Liturgia a misterium paschalne Chrystusa, w: Wprowadzenie do liturgii, zwł. s. 13-14; ks. A. S k ow r on e k, Kościót jako Prasakrament, ,At. Kapł.” 68 (1965) nr 336-337, s. $1-10$, zwł. 3-5. 
w swój cielesno-duchowy sposób trwale obecny w Chrystusie uwielbionym, dlatego też sakramenty św. jako osobiste akty Chrystusa w Kościele są rzeczywiście misteriami, czyli sprawowaniem w misteriach odkupienia dokonanego przez Chrystusa, są sprawowaniem - w misteriach przeszłych zbawczych aktów życia Chrystusa, zwłaszcza Jego historycznej ofiary krzyża. Kościół jednak w swojej liturgii jest nie tylko kontynuacją ziemskiego życia Chrystusa, ale przede wszystkim przedłużeniem na ziemi samego Chrystusa obecnego w niebie i właśnie dlatego pełni te funkcje zbawcze, jakie na ziemi spełniało ciało Jezusa ${ }^{16}$.

Po Soborze Watykańskim II teologowie jeszcze wyraźniej piszą o sakramentalnym uobecnieniu Paschy Chrystusa w Kościele i określają Kościół jako sakrament Chrystusowej Paschy. Wymienię przykładowo trzech autorów. V. W a rn a ch, znany od lat zwolennik i obrońca poglądów O. Casela twierdzi, komentując dokumenty soborowe, że Kościół jest samą ,tajemnicą paschalną”, którą obchodzi w swej liturgii, a noc Zmartwychwstania jest nocą godową Kościoła; wyrażenie mysterium paschale odnosi się także w Konstytucji o Liturgii w sposób jednoznaczny do Kościoła, a określenie Kościoła w czasie drugiego okresu obrad soborowych jako „walczącego” i ,zwalczanego” było przypomnieniem, że jest to przede wszystkim Kościół dźwigający Krzyż i razem z Panem ukrzyżowany, ale jednocześnie z Nim stanowiący Paschę. Autor pisze dalej, że wg Konstytucji o Kościele chrzest jest wspólnotą śmierci i zmartwychwstania z Panem. Eucharystia tę wspólnotę losu z Chrystusem urzeczywistnia w sposób jeszcze bardziej konkretny. Kościół jest eucharystyczną wspólnotą ofiary i życia Chrystusa. Podobnie i życie oraz śmierć poszczególnego chrześcijanina stają się współumieraniem i współwywyższeniem z Chrystusem ${ }^{17}$. H. M ü h l e n, czołowy realizator pneumatologicznej odnowy eklezjologii i chrystologii pisze, że ofiara krzyża na mocy Ducha Bożego stanowi ofiarowanie się Jezusa raz po wsze czasy i chociaż stanowi fakt zbawczy dokonany w minionej historii to obejmuje także najodleglejszą przyszłość. Twierdzi, że Duch Swięty, wysłużony nam przez

16 Por. przede wszystkim: Chrystus sakrament spotkania z Bogiem, zwł. s. 3746, 71-74, 80-90; Sakramente als Organe der Gottbegegnung, w: Fragen der Theologie heute (hrsg. von J. Feiner, J. Trütis h, F. B öickle), Einsiedeln-Zürich-Köln 1957, s. 3179-401, zwł. 3910-3911; Godsdienst en sacrament, ,Studia Catholica" 34 (1959), s. 267-283, zwł. 272-273. Por też m.in. W. Grana t, Dogmatyka katalicka, t. VII/1. s. $26-28$ i 134; A. Sk ow r onek, Kościót jako prasakrament, s. 5-6; Tenże, Chrystologiczne podstawy Kościoła jako prasakramentu, s. 97$100 ;$; W. Hryniewicz, Liturgia a misterium paschalne Chrystusa, s. 76-77; I. R ó ż y c k i, Podstawy sakramentologii, s. $170 \longrightarrow 180$.

17 Por. np. Kościót jako tajemnica, w: Nowy obraz Kościoła po Soborze Watykańskim II. Praca zbiorowa pod red. B. L a m bert a OP (Przekład zbiorowy $\mathrm{z}$ wydania franc. pt. Nouvelle image de l'Eglise - Bilan du Concile Vatican II, Tours 1967), Warszawa 1968, s. 26-32, zwł. 31-32, p. 28; T e n ż e, Kościót jako sakrament, t a mże, s. $32-38$, zwł. 25-316; t e nże, Christus-Misterium, Graz-Wien-Köln 1977, zwl. s. 165-16\% i 2311-2233. 
śmierć Jezusa, uobecnia na trwałe jednorazowość historycznego wydarzenia Chrystusa; Jego słowa i Jego zbawcze dzieło trwają nadal wśród nas mocą upamiętniającej funkcji Jego Ducha ${ }^{18}$. W. Kas per, autor znanej syntezy chrystologicznej pt. Jezus Chrysus akcentuje samo pojęcie Ducha (Pneuma) jako sposobu, w którym jednorazowa osoba i jednorazowe dzieło Jezusa Chrystusa osiągają uniwersalną skuteczność oraz mogą być doświadczone historycznie „po ludzku”. Duch jest skuteczną obecnością wywyższonego Pana w Kościele, w poszczególnych wiernych i w świecie ${ }^{19}$.

Szczupłe ramy komunikatu nie pozwalają na głębszą analizę i wnikliwą ocenę zarysowanych tutaj teorii. Spróbuję jednak dokonać jakiegoś podsumowania w formie następujących wniosków:

Określanie Kościoła sakramentem Paschy Chrystusa nie jest czystą metaforą, ale wskazuje na istotny aspekt rzeczywistości eklezjalnej. Mówiąc o uobecnianiu się tajemnicy paschalnej w Kościele i w poszczególnym życiu chrześcijańskim, winniśmy to rozumieć nie tylko w sensie symbolicznym czy w znaczeniu naśladowania Chrystusa w życiu moralnym, ale w jakimś znaczeniu głębszym. Podobnie mówiąc o związku sakrametów św. z tajemnicą paschalną, nie możemy poprzestać na twierdzeniu, że skuteczność uświęcającego działania tych obrzędów płynie $\mathrm{z}$ ofiary paschalnej Chrystusa. Z drugiej strony rozumiemy dobrze, że nie można mówić o uobecnianiu czy powtarzaniu jakichkolwiek faktów $\mathrm{z}$ życia Jezusa ziemskiego $\mathrm{w}$ ich historycznej konkretności. Można natomiast mówić o jakimś trwaniu czy uwiecznieniu wydarzeń zbawczych $\mathrm{w}$ ich najgłębszej istocie $\mathrm{i} \mathrm{w}$ ich powiązaniu z Chrystusem uwielbionym, uobecniającym się wielorako dzięki Duchowi Swiętemu. Wydaje się, że dalsze próby wyjaśnienia uobecniania się tajemnicy paschalnej w Kościele i w jego liturgii winny wychodzić od bardziej pogłębionych analiz takich pojęć, jak misterium (jego trwały charakter i różne formy uobecniania się) i anamneza (jako nie samo wspomnienie, ale pamiątka dynamiczna umożliwiająca jakąś egzystencjalną łączność z tym, co było istotne i pełne mocy w wydarzeniach zbawczych). Należałoby też przeanalizować pojęcie różnorakiej obecności i wielorakiego uczestnictwa. Te wszystkie analizy dokonane w oparciu o dane biblijne i patrystyczne a także w nawiązaniu do niektórych kategorii znanych z filozofii nie tylko przyczynią się do głębszego zrozumienia tajemnicy paschalnej, ale też do

18 Por. np. Das Christusereignis..., s. 533-5144. Por. też A. N o s Sol, Teologia na ustugach wiary, s. $179-180$. Jest to fragment rozdlziału opublikowanego weześniej jako artykul pt. Per Christum et in Christo. Kierunki wspótczesnej chrystologii katolickiej, „Collectanea Theologica” 45 (1975), z. 4, s. 5-28.

19 Por. Jezus Chrystus, s. 266. Por. też A. N os Sol, Teologia na ustugach wiary, s. 180 . 
zweryfikowania dotychczasowych teorii próbujących ją wyjaśnić i do stworzenia jakiejś teorii, ujmującej tę tajemnicę bardziej całościowo w najrozmaitszych jej aspektach.

\section{REPRESENTATION ISACRAMENTELLE DE LA PÂQUE DU CHRIST}

\section{R és u m é}

La Pâque du Christ, événement central de sa vie et de son activité salutaire présente une valeur permanente pour la vie de l'Eglise eit pour sa mission.

La théologie traditionelle enseignait, que dans la vie de l'Eglise et aussi dans la liturgie dels sacramenits ne sonit représentés que deis effelcts salultailres des événements paiscals. En même temps les fidèles son't invités à suivre le Christ souffrant et ressuscité. C'est seulement en Eucharistie que s'effectue la représentation réelle et mystérieuse de l'offrande pascale du Chrisit.

Les icauses diverses comme le développement des rechercheis sur le isens du „mysterium” dans l'Ecrilture elt chez les Pères, le mouvement liturgique, l'approfondisisement théologiquie de la liturgie, le développement de l'ecclésiologie et de la christologie en leurs relattions strictes avec la pneumatologie, ont conduit à une découverte de la valeur permanente de la Pâque du Christ et de son influence sur la missilion die l'Egllise. Le premier essai de celtte nouvelle interprétaltion était la thélorie dess mysitèress, créée par O. Casel et moldifiée par G. Söhingen et A. V'onier. D'autres esisaiis d'interprétation plus profondie ont été elaborés par L. Monden, K. Rahner, O. Semmelroth, E. Schillebeeckx et derniérement par V. Warnach, H. Mühlen, W. Kasper et par beacoup d'autres. Ces interprétations nouvelles oint sans doulte influencé la doctrine du Vatican II sur les relaitions initimies entre la Pâque du Christ et toute la vie, surtout sacramentelle, de l'Eglise.

En guise de conclusion il faut dire que tous les énoncés sur l'Eglise comme sacrement de la Pâque, sur la représentation réelle idu myistère pasical dans l'Eglise et sur les rapports de mylstère avec les sacraments doivent être compris en sens réel, et non pas metaphorique. La raison de cela es't le caractère permanent des événementis pascals, causé par leur's rapports intimes avec le Christ glorifié, présent invisiblement en son Eglise.

Il faut continuer des recherches concernant ces problèmes, surtout basées sur l'analyse profonde de telles notions fondamentaleis comme „mystère”, „mémorial” (annamnèse), ,présence” et „participation” ou ,communicaltion”. 